\title{
Deteksi Dini Kanker Serviks dengan IVA Test pada Kelompok Rentan Terkena HIV
}

\author{
Early Detection of Cervical Cancer with IVA Test in HIV-Reluctant Groups \\ Dhesi Ari Astuti ${ }^{1}$, Nurul Kurniati ${ }^{2}$ \\ ${ }^{1,2}$ Universitas 'Aisyiyah Yogyakarta, Yogyakarta \\ dhesi stikesayo@yahoo.co.id ${ }^{1}$, nurul.kurnati@,unisayogya.ac.id ${ }^{2}$
}

Riwayat Artikel: Dikirim 30 November 2018; Diterima 9 Mei 2019; Diterbitkan 31 Mei 2019

\begin{abstract}
Abstrak
Di Indonesia, jumlah kasus baru HIV positif yang dilaporkan pada Tahun 2015 sebanyak 30.935 kasus, menurun dibandingkan tahun sebelumnya. Perkumpulan Ibu-ibu Dasa Wisma Seruni merupakan perkumpulan ibu-ibu di wilayah Balecatur yang memiliki karakteristik dari segi profesi beragam, meliputi tenaga kesehatan, tenaga kependidikan, dan $70 \%$ adalah IRT. Jenis pekerjaan yang dimiliki jika diperhatikan merupakan jenis pekerjaan yang rentan terhadap penularan HIV/AIDS dan paparan HIV/AIDS ini erat kaitannya dengan Kanker Serviks yaitu sopir truk antar kota, pelayar kapal, tenaga kerja di Arab. Balecatur merupakan wilayah di Kabupaten Sleman yang keberadaannya dekat dengan Jalan Wates sehingga merupakan wilayah yang berisiko dengan akses ke penjaja seks tidak langsung. Tujuan kegiatan adalah transfer informasi dan skrining Ca.Cerviks memlaui pemeriksaan IVA pada ibu rumah tangga di wilayah Dasawisma Dusun Ngaran Balecatur. Metode pelaksanaan kegiatan dengan melakukan skrining pada ibu ibu di perkumpulan Dasawisma Seruni Balecatur, karena skrining ini terutama dilakukan pada kelompok yang rentan terhadap paparan HIV yakni karena telah di ketahui bahwa pada kelompok ini akan lebih mudah terkena paparan HPV penyebab kanker serviks. Skrining dilakukan pada 15 ibu dasawisma yang telah dilakukan anamnesa dan pemeriksaan vtal sign terlebih dahulu. Kegiatan IbM skrining IVA ini hasilnya dari 15 ibu terdapat 13 hasil normal dan 2 ibu perlu rujukan ke puskesmas. Sebagai upaya tindak lanjut dari kegiatn ini diperlukan kerjaam dengan lintas sektor baik itu perangkat desa di masyarakat maupun dengan sektor penyedia layanan kesehatan untuk dapat melakukan kegiatan serupa secara rutin sehingga bisa menjamin kualitas kesehatan masyarakat pada umumnya.
\end{abstract}

Kata kunci: deteksi dini, kanker serviks, IVA.

\begin{abstract}
In Indonesia, the number of new HIV positive cases reported in 2015 was 30,935 cases, down from the previous year. The Dasawisma Seruni is an association of mothers in the Balecatur region who have various professional characteristics, including health workers, education staff, and 70\% are IRTs. The type of work that is owned if it is considered is the type of work that is susceptible to HIV / AIDS transmission and exposure to HIV / AIDS is closely related to Cervical Cancer namely inter-city truck drivers, ship sailors, workers in Arabia. Balecatur is an area in Sleman Regency which is close to Wates Street, making it a risky area with access to indirect sex workers. The purpose of the activity was the transfer of information and screening of Cervical Cancer through IV A examination in housewives in the Dasawisma area of Ngaran, Balecatur. The method of carrying out activities is by screening mothers in the Dasawisma Seruni Balecatur, because screening is mainly done in groups vulnerable to $H I V$ exposure because it is known that this group will be more susceptible to exposure to HPV causing cervical cancer. Screening was carried out on 15 charismatic mothers who had done anamnesa and vtal sign examination first. The IbM IV A screening activity results from 15 mothers with 13 normal results and 2 mothers needing referral to the puskesmas. As a follow-up effort, these activities require cross-sectoral work, both village officials in the community and with the bealth care provider sector to be able to carry out similar activities on a regular basis so that they can guarantee the quality of public health in general.
\end{abstract}

Keywords: screening, cervical cancer, IVA.

\section{PENDAHULUAN}

Terdapat 35 juta orang hidup dengan Human Immunodeficiency Virus (HIV) di seluruh dunia, 16 juta di antaranya adalah perempuan, 3,2 juta adalah anak di bawah 15 tahun, infeksi baru sebanyak 2,1 juta serta jumlah Kematian akibat AIDS sebanyak 1,5 juta di Tahun 2013 (Ditjen PP \& PL 
Kemenkes RI \& Kementrian Kesehatan RI, 2014). Di Indonesia, jumlah kasus baru HIV positif yang dilaporkan pada Tahun 2015 sebanyak 30.935 kasus, menurun dibandingkan tahun sebelumnya (Kementerian Kesehatan Republik Indonesia, 2015).

Pada wanita yang terinfeksi HIV (ODHIV), potensi untuk terkena infeksi lain bahkan infeksi Human papillomavirus (HPV) penyebab kanker serviks sangat dimungkinkan tentu saja karena kerentanan sistem tubuh. ODHIV mempunyai risiko terkena paparan HPV lebih tinggi dibanding dengan wanita yang tidak HIV (Hawes et al., 2003; Jin, Liu, Ding, Zhang, \& He, 2017; Serraino et al., 1999). HIV dan HPV memiliki jalur transmisi seksual oleh karena itu hubungan antara HIV dan kanker serviks dapat dijelaskan oleh seringnya infeksi atau paparan HPV pada ODHIV atau paparan langsung terhadap infeksi HIV berkaitan dengan kekebalan tubuh dapat meningkatkan persistensi infeksi HPV (World Health Organization, 1996). Terlebih lagi HIV dan HPV mempunyai faktor risiko yang sama seperti usia dini saat melakukan hubungan seksual, berganti pasangan dan aktivitas seksual yang tidak aman (Banura et al., 2011; Kasamba, Sully, Weiss, Baisley, \& Maher, 2011).

Perkumpulan ibu-ibu Dasa Wisma Seruni merupakan perkumpulan ibu-ibu di wilayah Balecatur yang memiliki karakteristik dari segi profesi beragam, meliputi tenaga kesehatan, tenaga kependidikan, dan $70 \%$ adalah IRT. IRT tentunya akan menggantungkan pendapatan dari suami, karena suami yang lebih utama mencari nafkah. Jenis pekerjaan yang dimiliki jika diperhatikan merupakan jenis pekerjaan yang rentan terhadap penularan HIV/AIDS dan paparan HIV/AIDS ini erat kaitannya dengan Kanker Serviks yaitu sopir truk antar kota, pelayar kapal, tenaga kerja di Arab. Balecatur sendiri merupakan wilayah di Kabupaten Sleman yang keberadaannya dekat dengan Jalan Wates sehingga merupakan wilayah yang berisiko dengan akses ke penjaja seks tidak langsung.

\section{METODE}

Solusi yang ditawarkan berupa pencegahan dalam bentuk deteksi dini dan skrining kanker serviks dengan IVA Test pada wanita yang rentan terkena paparan HIV/AIDS. Pencegahan memiliki makna deteksi dini atau skrining, yakni pemeriksaan atau tes yang dilakukan pada orang yang belum menunjukkan adanya gejala penyakit atau masih berada dalam stadium praklinik (Rasjidi, 2009).

Skrining pada ibu ibu di perkumpulan Dasawisma Seruni Balecatur, karena skrining ini terutama dilakukan pada kelompok yang rentan terhadap paparan HIV yakni karena telah di ketahui bahwa pada kelompok ini akan lebih mudah terkena paparan HPV penyebab kanker serviks. Jika fasilitas tersedia, skrining dilakukan tiap 5 atau 10 tahun pada wanita usia 35 sampai 55 tahun, sedangkan skrining yang ideal adalah tiap 3 tahun pada wanita usia 25 sampai 60 tahun (Rasjidi, 2009).

\section{HASIL DAN PEMBAHASAN}

Kegiatan pengabdian masyarakat detekksi dini Ca. Cervikx ini diawali dengan kegiatan koordinasi dengan ketua dasawisma Seruni di Dusun Ngaran. Hal ini sebagai perwujudan dari pengabdian masyarakat dosen dengan memberdayakan perempuan di masyarakat untuk kesadarannya memeriksakan kesehatan dirinya. Koordinasi dengan ketua dasawisma disambut baik dengan akan berlanjutnya kegiatan pemaparan informasi terkait pentingnya pemeriksaan deteksi dini pada ibu dengan resiko Ca. Cervix, dima Ca. cervix adalah penyakit yang mematikan bagi perempuan. Kegiatan koordinasi ini dilaksanakan pada di rumah ketua dasawisma Seruni.

Kegiatan tahap dua adalah kegiatan pemaparan informasi Ca. Cerviks sebagai tindakan penyuluhan dan membangun kesadaran perempuan tentang pentingnya 
kesehatan organ kewanitaan dalam hal ini sebagai organ vital. Kegiatan penyuluhan ini diikuti 17 peserta dari anggota dasawisma seruni dan dilaksanakan pada Januari 2018 di Dusun Ngaran. Kegiatan ini disambut antusiasme dari peserta, dan diikuti dengan baik oleh semua peserta. Materi yang diberikan pada penyuluhan ini antara lain meliputi : definisi dari Ca. Cerviks, gejala, deteksi dini dan penanganan dari Ca. Cerviks. Selain itu disampaikan pula tentang proses pemeriksaan IVA sebagai salah satu deteksi dini dari Ca. Cerviks. Sebagai tindak lanjut dari pertemuan ini adalah melakukan koordinasi dengan peserta hari pelaksanaan kegiatan skrining $\mathrm{Ca}$. cerviks yang akan diadakan di waktu yang akan datang.

$$
\text { Pada bulan April dilakukan }
$$
pemeriksaan IVA bagi seluruh peserta dassawisma yang telah dilakukan informed cosent sebelumnya. Kegiatan ini dihadiri oleh 15 peserta. Teknis kegiatan ini ibu dilakukan informed consent, pemeriksaan Vital Sign, lalu dilakukan skrining penaposan untuk beberapa penyakit dan riiwayat kesehatan. Selanjutnya dilakukan pemeriksaan IVA secara bergantian. Hai dari kegiatan ini dari 15 peserta diperoleh 13 peserta hasil IVA baik, dan 2 peserta perlu pemeriksaan lanjutan di Puskesmas wilayah setempat sebagai tindak lanjut hasil pemeriksaan saat ini.

\section{Gambar 1}

Kegiatan Sosialisasi Pemeriksaan IVA

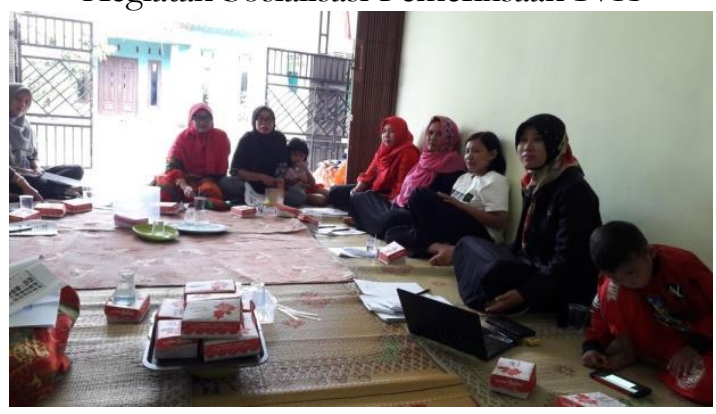

Sumber: Dokumentasi Pribadi

Pemeriksaan IVA sebagai skrining terhadap kanker serviks sangat dipengaruhi oleh pengetahuan tentang factor resiko, perilaku dan deteksi dini. Berdasarkan penelitian Sulistiowati (2014) di Bogor terdapat 3.8\% dari 3303 ibu yang telah melakukan pemeriksaan IVA. Selain itu dari sejumlah ibu terdapat $17.3 \%$ yang memiliki pengetahuan tentang penyebab kanker serviks adalah HPV dan 19,3 yang memahami tentang faktor resiko terjadinya kanker serviks.

Berdasarkan kajian beberapa penelitian menunjukkan bahwa IVA membantu dalam mengurangi nrujukan untuk kolposkopi tanpa mengurangi kualitas pelayanan. Slawson menyatakan pasien yang memiliki hasil biopsy serviks abnormal, tes IVA dapat mendeteksi hingga 64\% kasus. Disimpulkan bahwa tes IVA dapat digunakan sebagai pelengkap terhadap tes PapSmear dalam deteksi dini kanker serviks (WHO, 2005).

\section{KESIMPULAN}

Kegiatan IbM skrining IVA ini dapat terlaksana dengan. Selain itu perlu adanya kordinasi ke faskes tingkat lanjutan sebagai tindak lanjut hasil dari kegiatan pemeriksaan sebelumnya. Haasilnya dari 15 ibu terdapat 13 hasil normal dan 2 ibu perlu dirujuk ke faskes.Sebagai upaya tindak lanjut dari kegiatan ini diperlukan kerjasama dengan lintas sektor baik itu perangkat desa di masyarakat maupun dengan sektor penyedia layanan kesehatan untuk dapat melakukan kegiatan serupa secara rutin sehingga bisa menjamin kualitas kesehatan masyarakat pada umumnya.

\section{DAFTAR PUSTAKA}

Chirenje, Z. M. (2005). HIV and cancer of the cervic. Best Practice and Research: Clinical Obstetrics and Gynaecology, 19(2 SPEC. ISS.), 269-276. https://doi.org/10.1016/j.bpobgyn.2 004.10.002

Denny, L., \& Anorlu, R. (2012). Cervical cancer in Africa. Cancer Epidemiology Biomarkers and Prevention, 21(9), 1434 1438. https://doi.org/10.1158/10559965.EPI-12-0334

Ditjen PP \& PL Kemenkes RI, \& 
Kementrian Kesehatan RI. (2014). Infodatin AIDS dan Data Statistik HIV dan AIDS di Indonesia 2014. Kemenkes RI.

Ginindza, T. G., Dlamini, X., Almonte, M., Herrero, R., Jolly, P. E., TsokaGwegweni, J. M., ... Sartorius, B. (2017). Prevalence of and Associated Risk Factors for High Risk Human Papillomavirus among Sexually Active Women, Swaziland. PLoS ONE, 12(1), e0170189.

https://doi.org/10.1371/journal.pone .0170189

Hawes, S. E., Critchlow, C. W., Faye Niang, M. a, Diouf, M. B., Diop, A., Touré, P., ... Kiviat, N. B. (2003). Increased risk of high-grade cervical squamous intraepithelial lesions and invasive cervical cancer among African women with human immunodeficiency virus type 1 and 2 infections. The Journal of Infectious Diseases, 188(4), 555-563. https://doi.org/10.1086/376996

Jin, Z.-Y., Liu, X., Ding, Y.-Y., Zhang, Z.F., \& He, N. (2017). Cancer risk factors among people living with HIV/AIDS in China: a systematic review and meta-analysis. Scientific Reports, 7, 4890. https://doi.org/10.1038/s41598-01705138-x

Kasamba, I., Sully, E., Weiss, H. A., Baisley, K., \& Maher, D. (2011). Extra-spousal partnerships in a community in rural Uganda with high HIV prevalence: a cross-sectional population-based study using linked spousal data. Journal of Acquired Immune Deficiency Syndromes (1999), 58(1), 108-114. https://doi.org/10.1097/QAI.0b013e 318227af4d

Kementerian Kesehatan Republik Indonesia. (2015). Profil Kesehatan Indonesia Tabun 2015.

Kementrian Kesehatan RI Pusat Data dan Informasi Kesehatan. (2015). Situasi Penyakit Kanker. Infodatin-Kanker, hal 3.

Megevand, E., Denny, L., Dehaeck, K.,
Soeters, R., \& Bloch, B. (1996). Acetic acid visualization of the cervix: An alternative to cytologic screening. Obstetrics and Gynecology, 88(3), 383-386. https://doi.org/10.1016/00297844(96)00189-5

Millicent Ndikom, C., \& Abosede Ofi, B. (2012). Awareness, perception and factors affecting utilization of cervical cancer screening services among women in Ibadan, Nigeria: a qualitative study. Reproductive Health, 9, 1. https://doi.org/10.1186/1742-47559-11

Mupepi, S. C., Sampselle, C. M., \& Johnson, T. R. (2011). Knowledge, attitudes, and demographic factors influencing cervical cancer screening behavior of Zimbabwean women. I Womens Health (Larchmt), 20(6), 943-952. https://doi.org/10.1089/jwh.2010.20 62

Sauvaget, C., Fayette, J.-M., Muwonge, R., Wesley, R., \& Sankaranarayanan, R. (2011). Accuracy of visual inspection with acetic acid for cervical cancer screening. International Journal of Gynaecology and Obstetrics: The Official Organ of the International Federation of Gynaecology and Obstetrics, 113(1), 14-24. https://doi.org/10.1016/j.ijgo.2010.1 0.012

Serraino, D., Carrieri, P., Pradier, C., Bidoli, E., Dorrucci, M., Ghetti, E., ... Rezza, G. (1999). Risk of invasive cervical cancer among women with, or at risk for, HIV infection. International Journal of Cancerr, 82(November 1998), 334-7. Sulistowati, Eva., Sirait, Ana Maria. (2014). Pengetahuan tentang Faktor Resiko, Perilaku dan Deteksi Dini Kanker Serviks dengan IVA pada Wanita di Kecamatan Bogor Tengah, Kabupaten Bogor.. Buletin Peelitian Kesehatan. Vol.2. No.3, September 2014: 193-202 UNAIDS, W. (2009). AIDS Epidemic Update 2009. Joint United Nations Programme on HIV AIDS UNAIDS and World Health Organization WHO, 
WHO. IARC. Handbooks of cancer prevention: Cervical Cancer screening(e-book) Edisi ke-10 Lyon. IARC Press: 2005 Link: http://gigapedia.com/items:link?eid= nXa\%2F5gAJPi\%Fd5wiYebMSSGBB bZUgonjJLBR931XF161\%3D 